Review

\title{
Refolding Technology for scFv Using a New Detergent, $N$-Lauroyl-L-glutamate and Arginine
}

\author{
Tsutomu Arakawa $^{1, *}$, Yoshiko Kita ${ }^{2}$ and Daisuke Ejima ${ }^{3}$ \\ 1 Alliance Protein Laboratories, 3957 Corte Cancion, Thousand Oaks, CA 91360, USA \\ 2 Department of Pharmacology, KEIO University School of Medicine, Tokyo 160-8582, Japan \\ 3 Institute for Innovation, Ajinomoto Co. Inc., Kanagawa 210-8681, Japan \\ * Author to whom correspondence should be addressed; E-Mail: Tarakawa2@ aol.com; \\ Tel.: +81-805-388-1074; Fax: +81-805-388-7252.
}

Received: 10 July 2012; in revised form: 16 August 2012 / Accepted: 21 August 2012 /

Published: 29 August 2012

\begin{abstract}
Monoclonal antibodies to the soluble antigens or cell surface markers hold great promise as effective human therapeutics. One of the major disadvantages is its large size, which prevents efficient penetration into the target tissues. Smaller version of antibodies, which has only antigen binding sites, is extensively investigated. It becomes increasingly apparent, however, that these smaller fragments of antibodies are rather difficult to produce, as the normally efficient mammalian secretion system does not work well for these fragments. Thus, refolding of insoluble proteins produced in Escherichia coli is a method of choice, although such refolding is mainly based on trial-and-error experiment. Here we describe a novel refolding system using a new amino acid-based detergent, $N$-lauroyl-L-glutamate, and arginine. This detergent appears to readily dissociate from proteins below critical micelle concentration (CMC), while remaining effective in protein solubilization above CMC. Arginine suppresses protein aggregation when the detergent concentration was reduced below CMC. The interaction of the detergent and arginine with proteins, which play an important role in protein refolding, will be discussed in great length.
\end{abstract}

Keywords: $N$-lauroyl-L-glutamate; arginine; refolding; scFv; interleukin-6; transglutaminase 


\section{Introduction}

Monoclonal antibodies occupy a large fraction of biopharmaceutical proteins [1] and can be readily produced by a platform technology with extremely high expressions and efficient downstream processes [2-6]. One of the major disadvantages using the whole antibody is its large size, which limits penetration into diseased areas [7-9]. Antibody-dependent cellular cytotoxicity (ADCC) or complement-dependent cytotoxicity (CDC) functions mediated by binding of the Fc domain of the whole antibodies to the Fc receptor also limits the circulation and mobility [10]. Smaller version of antibody, lacking Fc-domains, can overcome these problems, provided that the ADCC or CDC function is not required for therapeutic efficacy of the antibodies [11-14]. One of them is a construct linking two variable domains, i.e., heavy and light chains, of antibody with a flexible spacer, called single-chain antibody (scFv) [15,16]. Such scFv molecules normally retain the original antigen specificity and affinity [14]. A number of functional adducts have been fused to the scFv, creating novel dual-functional antibody fragments, including biosensors for detection [17], cytokines for immunotherapy [18,19] and radioisotopes for imaging and cytotoxicity [20,21]. Conjugation of scFv with cytotoxic agents is particularly attractive for treatments against solid tumors, such as breast cancers [22-25]. A small size also opens opportunity for the intracellular delivery of therapeutic antibody fragments [26-28].

It is increasingly apparent, however, that the mammalian secretion system, which is a major workhorse for the production of monoclonal antibodies [3-5,29] as well as other secretory proteins [30], is rather ineffective for antibody fragments due to both folding and aggregation problems [23,31,32]. On the contrary, $\mathrm{ScFv}$ can be readily produced in bacterial cells, in particular Escherichia coli (E. coli), often as inclusion bodies (IBs) [30-34]. When expressed as IBs, solubilization and subsequent refolding of the insoluble proteins are required for production of functional and soluble proteins. Various solubilization and refolding technologies have been developed using denaturants [35,36] or detergents [37-40]. Such refolding technologies have been applied to various antibody fragments [41-44]. We have developed a novel refolding technology using a new detergent, $\mathrm{N}$-lauroyl-L-glutamate (C12-L-Glu), as a solubilizing agent and arginine as an aggregation-suppressing and refolding-enhancing agent $[45,46]$. This review describes the refolding technology and the possible mechanism of how C12-L-Glu and arginine assist refolding processes.

\section{Refolding of Interleukin-6}

A number of acylamino acids are naturally present and hence can be physiologically metabolized. They are normally mild as a surfactant and possess various important properties as a household detergent [47]. Among various acylamino acids, $N$-lauroyl-L-glutamate (C12-L-Glu) appeared to be unique in certain detergent performances and physical properties: the chemical structure is depicted in Figure 1. It is composed of a C12 fatty acid and glutamic acid. Here, we focused on the ability of $N$-lauroyl amino acids to solubilize proteins from IBs and assist refolding. First, the ability to solubilize proteins from IBs was determined using insoluble interleukin-6 (IL-6) expressed in E. coli. IL-6 belongs in a 4-helical bundle family, which includes granulocyte colony stimulating-factor, growth hormone and many cytokines and interleukins. Many of them are produced by refolding of the 
protein from IBs. Thus, it should serve as a model for testing the ability to refold these important proteins. The IL-6 IBs were readily and completely solubilized by C12-L-Glu above $1.75 \%(\sim 50 \mathrm{mM})$, far above its CMC $(0.37 \%, 10.6 \mathrm{mM})$, indicating its strong dissolution properties. Various detergents were compared with C12-L-Glu in solubilization and refolding. Ideally, comparison should be made separately for solubilization and refolding. We have instead combined these properties in one experiment as described in Figure 2. The IL-6 IBs were solubilized by $2 \%$ C12-L-Glu and then diluted 20 -fold to a $0.05 \%$ detergent concentration with $10 \mathrm{mM}$ phosphate at $\mathrm{pH} 7.0$ containing disulfideexchange reagents. The refolding efficiency was determined by an analytical ion exchange chromatography-HPLC, which has been shown to separate the unfolded or partially folded species from the correctly folded native structure containing two intact disulfide bonds [48]. Thus, the overall yield is a product of solubilization and refolding processes. This simple dilution refolding normally gave an approximate yield of $\sim 50 \%$, demonstrating moderate efficiency of the refolding system. As dissolution of IL-6 IBs were nearly $100 \%$, less than $100 \%$ recovery is due to misfolding. Based on the simple refolding protocol described above (Figure 2), C12-L-Glu was better than other detergents tested. Figure 3 shows the results with different lauroyl (C12)-amino acids as well as some mild detergents. The \% recovery is normalized to the value for C12-L-Glu as $100 \%$. The actual recovery is about the half the values shown. Except for C12-L-Asp, all other lauroyl-amino acids showed low recovery, due to either less efficient solubilization or weaker ability to assist refolding or both. As both acidic amino acids (Glu and Asp) gave a high refolding yield, the chemical structure having an negatively charged side chain may play a role in this refolding process. Surprisingly, lauroyl-sarcosine (Sar) and lauric acid, commonly used detergents [40,49], were not effective. Since they are normally effective in solubilization of IBs, their ineffectiveness is most likely due to inability to assist refolding. It should be, however, noted that those ineffective detergents could be more effective than shown, when used under different refolding protocols. Nevertheless, it is remarkable that this rather simple dilution refolding leads to $\sim 50 \%$ efficiency with C12-L-Glu detergent. As expected, mild detergents, such as CHAPS, Triton X-100 and Tween 20 and 80, were ineffective due to their inability to solubilize IBs.

Refolding of IL-6 by C12-L-Glu was compared with other Glu-based detergents. As shown in Figure 4, both shorter and longer alkyl chains were less effective than C12-L-Glu. C11-L-Glu was about half effective and an increase in alkyl chain length (C13 and C14) significantly compromised the effectiveness. As acidic amino acids resulted in higher refolding efficiency, an additional Glu residue was added to C12-L-Glu either at $\gamma$-position (lauroyl- $\gamma$-GluGlu) or $\alpha$-position (lauroyl- $\alpha$-GluGlu) of the Glu residue. Both were not as effective as C12-L-Glu.

Figure 1. Chemical structure of $N$-lauroyl-L-glutamate (C12-L-Glu).

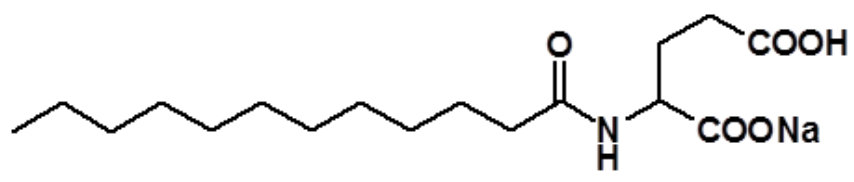


Figure 2. General refolding protocol for IL-6 and transglutaminase with C12-L-Glu.

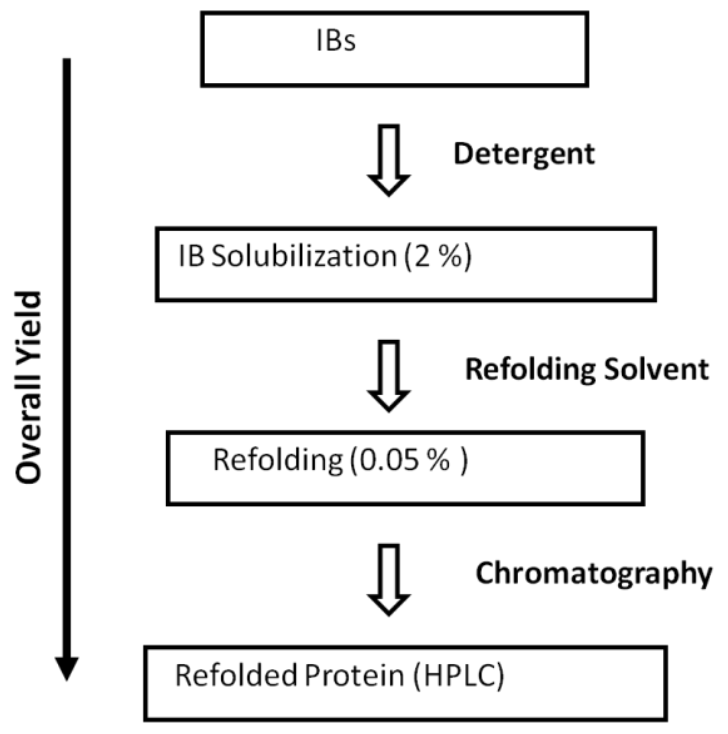

Figure 3. Refolding of IL-6 by lauroyl-amino acids or -derivatives and detergents. Sar, sarcosine. PCA (2-oxo-pyrrolidone carboxylic acid), pyroglutamate.

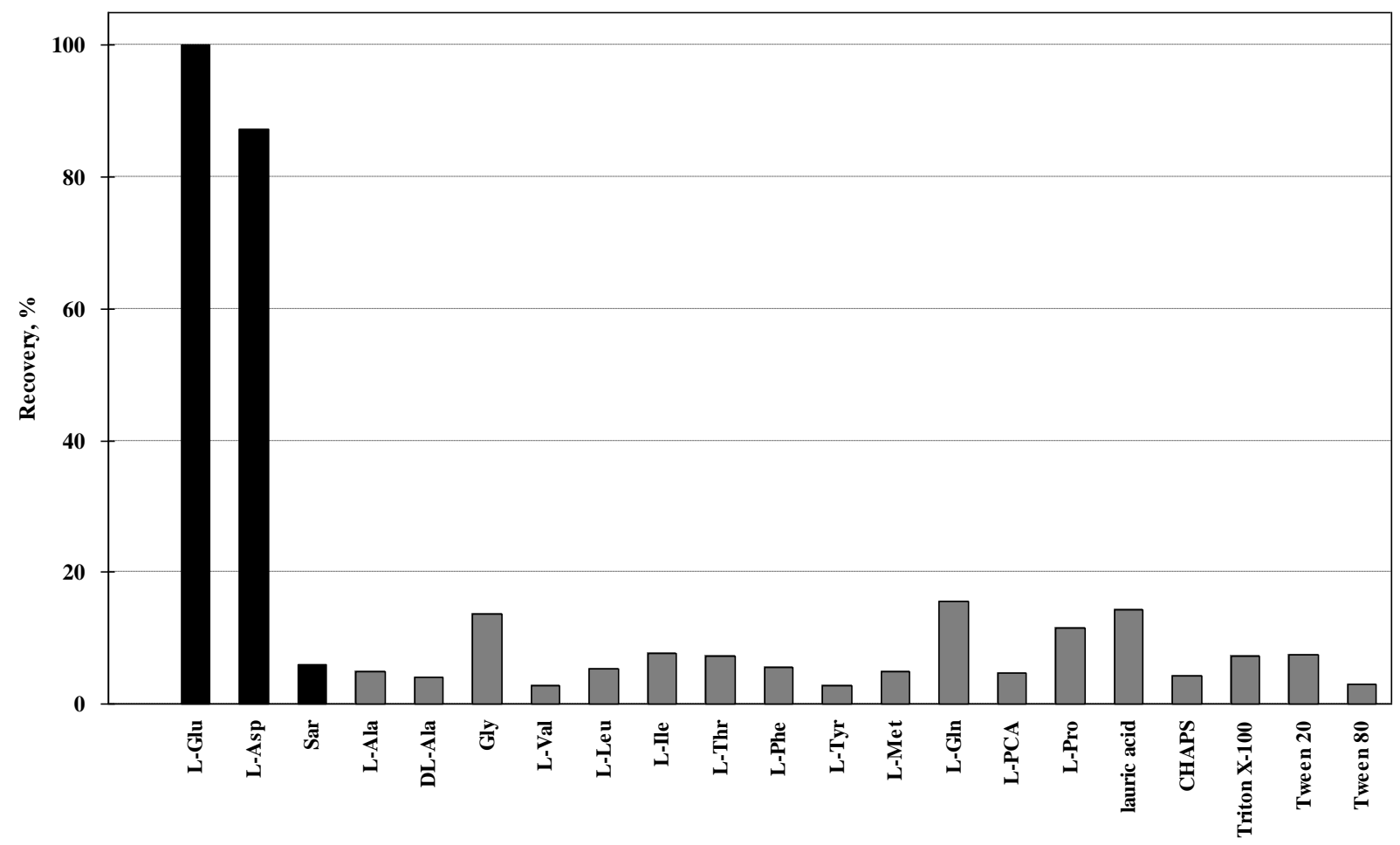

Detergents

Arginine has been extensively used to enhance refolding of proteins [50-65]. Its discover as a refolding assisting agent is rather surprising, considering its inhibitory effects on enzymatic activities [66,67]. Rudolph et al. [63] and Rudolph and Fisher [68] were working on refolding of plasminogen activator that cleaves substrates at arginine residue and thus considered a potential autolysis of the protein upon successful refolding that should generate active enzyme. They included free arginine molecule in the refolding mixture, assuming that the excess free arginine would compete with the arginine residues in the protein. This resulted in enhancement of refolding yield, rather than 
the inhibition, of plasminogen activator. Since this enzyme is specific for arginine, one might expect that the effect is protein-specific. It turned out that the effect is non-specific and broad $[50-65,69,70]$. Arginine showed such effects on numerous proteins, including those that have resisted different refolding approaches. As described later, this broad effect of arginine is due to its weak, but extensive binding to the proteins. The binding is not protein-specific. Although refolding of IL-6 was already moderate using the C12-L-Glu refolding system, whether arginine further improves the yield was tested. Figure 5 shows the relative yield in the presence of arginine. In this case, $2.5 \% \mathrm{C} 12-\mathrm{L}-\mathrm{Glu}$ solubilization and 50-fold dilution were used, leading to $\sim 70 \%$ yield. Since the yield was already high without arginine, the effects of arginine are moderate at $40 \%-60 \%$. Figure 5 shows $\%$ increase by arginine in refolding yield. As seen in Figure 5, 0.4 M arginine or even less may be sufficient for this case. Sucrose (0.4-1.2 M), glycerol (0.4-1.2 M) resulted in small increase (data not shown). On the contrary, butyroyl-arginine at 0.4-0.8 $\mathrm{M}$ arginine showed effects similar to, or better than, those of arginine.

Figure 4. Refolding of IL-6 by glutamate-based detergents.

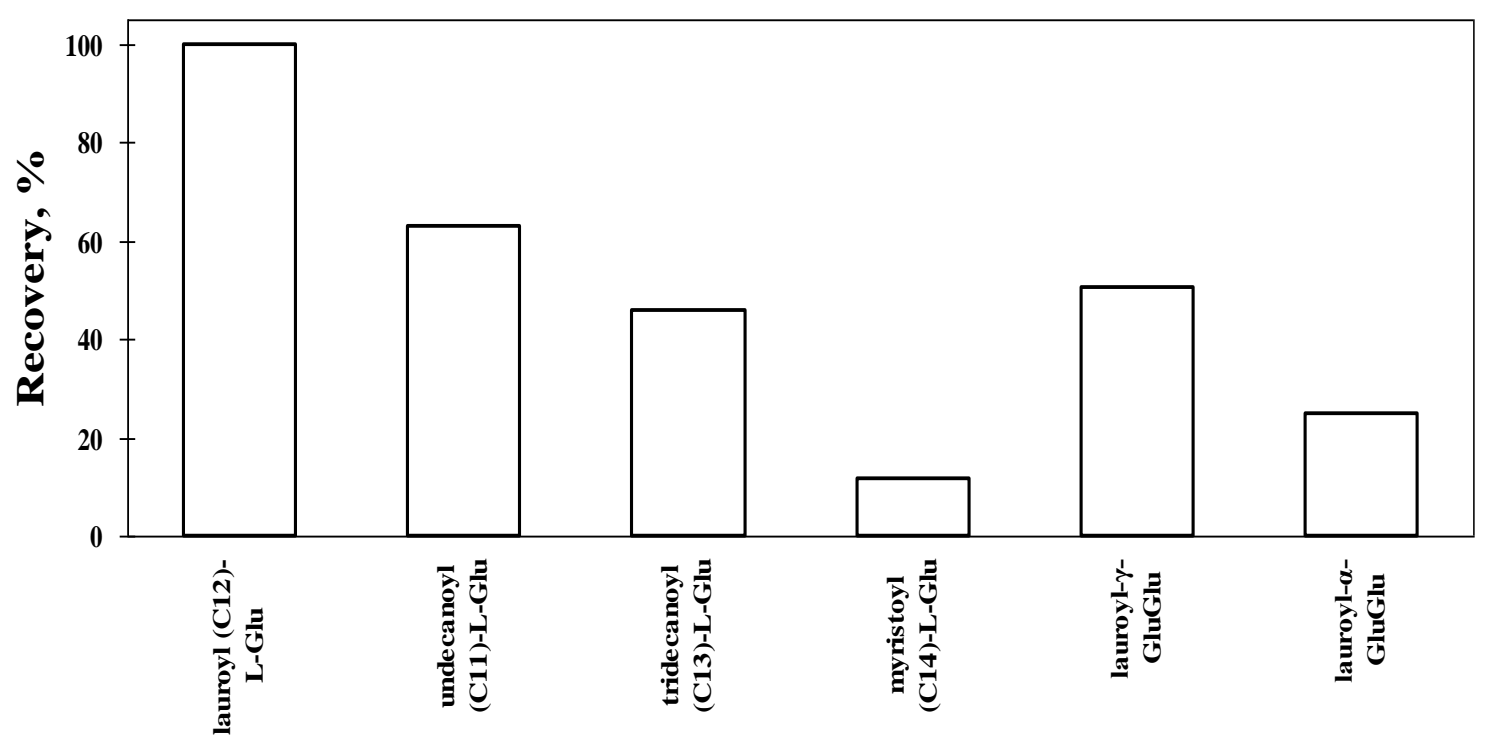

Detergents

Figure 5. Effect of arginine on refolding of IL-6 by C12-L-Glu.

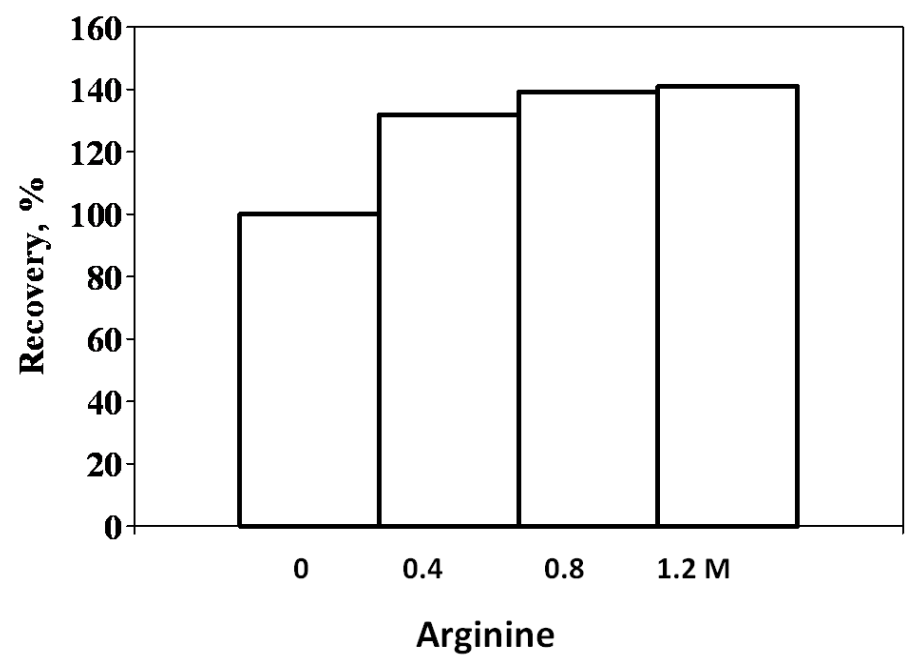




\section{Refolding of Transglutaminase}

Microbial transglutaminase was chosen as a model protein due to our extensive experience [71]. Refolding of transglutaminase requires a complex refolding procedure, comprising urea solubilization, $\mathrm{pH}$ shift, dilution refolding and another $\mathrm{pH}$ shift [71]. Even with this sophisticated process, the best yield was $\sim 29 \%$. We have applied the above refolding process to the IBs containing this enzyme: no transglutaminase activities were observed due to complete incorporation of this protein into IBs. The IBs were solubilized with $2 \%$ C12-L-Glu and refolded similarly. A one-step 40-fold dilution from $2 \%$ C12-L-Glu resulted in $24 \%$ yield, slightly less than the above complex refolding procedure. Inclusion of arginine greatly enhanced refolding yield concentration dependently, as plotted in Figure 6. The addition of $1.2 \mathrm{M}$ arginine resulted in $72 \%$ yield in one-step dilution (Exp.1). Not only the final yield but also the stability of the final product was different in the absence and presence of arginine. The transglutaminase refolded in the presence of arginine was more stable, perhaps due to the structure differences. It appears that the enzyme generated without arginine is trapped in an intermediate structure, while it gained a fully native structure in the presence of arginine. When the transglutaminase was refolded in two steps (Exp.2), i.e., 2-fold dilution of 2\% C12-L-Glu solubilized IBs followed by 20-fold dilution resulted in further increased refolding, in particular in the presence of arginine. The refolding yield sharply increased at higher arginine concentration, reaching $86 \%$ in $1.2 \mathrm{M}$ arginine. Since the final C12-L-Glu concentration is identical between the two refoldings, the observed small difference may be due to C12-L-Glu dependence of the structure of the solubilized transglutaminase. These refolded transglutaminases were fully active, equivalent to the microbial enzyme derived from the natural source.

Figure 6. Effect of arginine on refolding of transglutaminase by C12-L-Glu.

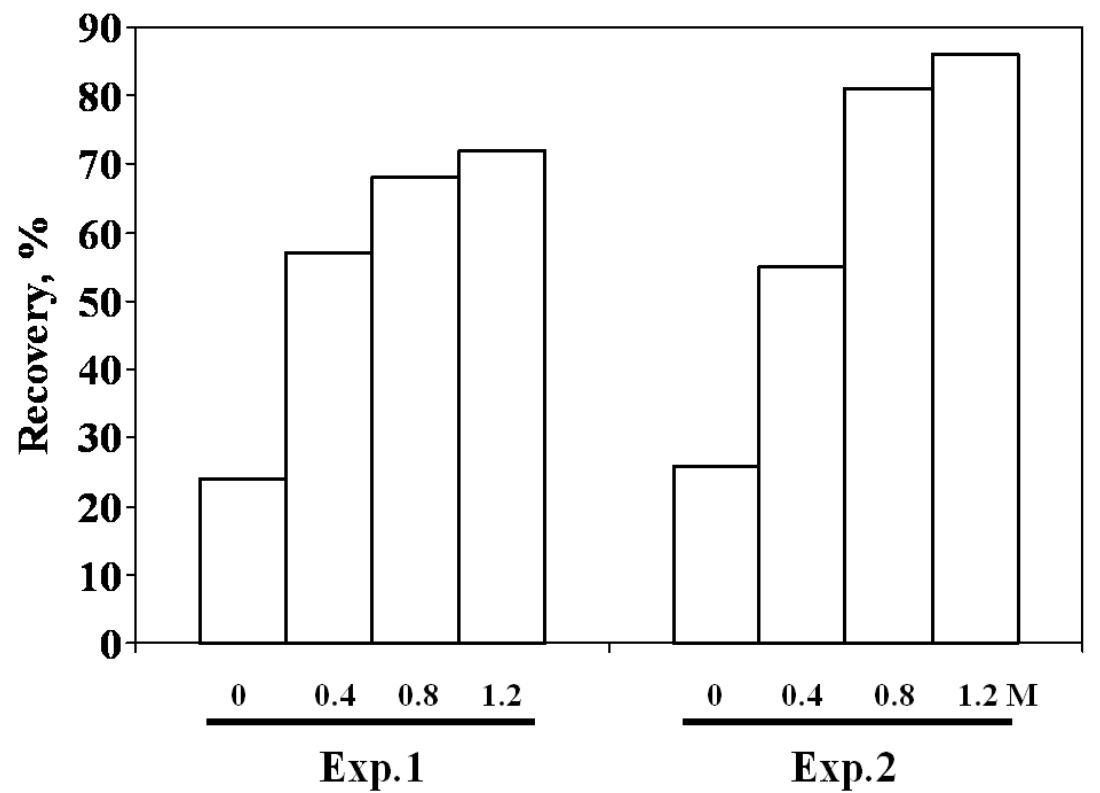

Arginine 


\section{4. $\operatorname{scFv}$}

Having established the basic concept of refolding using C12-L-Glu and arginine, we attempted to refold two scFv constructs expressed as IBs. One of them is a $\mathrm{scFv}$ derived from a monoclonal antibody, HyHEL-10. This antibody has been developed against hen egg lysozyme. Its binding to lysozyme inhibits enzymatic activity. The gene coding for HyHEL-10 scFv was expressed in E. coli, resulting in IBs. The IBs were dissolved with $2.5 \% \mathrm{C} 12-\mathrm{L}-\mathrm{Glu}, \mathrm{pH} 8.5$, at $15 \mathrm{mg} \mathrm{IB} / \mathrm{mL}$ (corresponding to $6 \mathrm{mg} \mathrm{scFv} / \mathrm{mL}$ ). Previously, we observed with transglutaminase refolding that the C12-L-Glu concentration impacts, though slightly, the refolding yield. As in the two-step dilution for transglutaminase, the 2.5\% C12-L-Glu solubilized IBs were diluted 2.5-fold with $\mathrm{pH} 8.0$ buffer (to a final C12-L-Glu concentration of 1\%): the overall protocol for scFv refolding is depicted in Figure 7. This was further 20-fold diluted with various refolding buffers containing $0.8 \mathrm{M}$ arginine and $0.05 \%-0.5 \% \mathrm{C} 12-\mathrm{L}-\mathrm{Glu}$ at $\mathrm{pH} 8.0$ (a final $\mathrm{scFv}$ concentration of $0.12 \mathrm{mg} / \mathrm{mL}$ ). The diluted solutions were incubated at $5{ }^{\circ} \mathrm{C}$ for $17 \mathrm{~h}$ (low temperature incubation) and then at $23{ }^{\circ} \mathrm{C}$ for $43 \mathrm{~h}$ (high temperature incubation). It was apparent in the initial experiments that a simple one-step dilution refolding with one incubation temperature, which was fairly effective for IL-6 and transglutaminase, was ineffective for this scFv and that such a complex procedure needs to be developed. The enhanced refolding by 2-step incubation suggests that the course of refolding of the HyHEL-10 scFv is complex and occurs via multiple steps. Refolding yield from the above series was determined as a function of C12-L-Glu concentration. As shown in Figure 8, the refolding yield was dependent on C12-L-Glu concentration. Even in the presence of $0.8 \mathrm{M}$ arginine, the yield was $38 \%$ at $0.05 \% \mathrm{C} 12-\mathrm{L}-\mathrm{Glu}$. Both IL-6 and transglutaminase showed a $>80 \%$ yield under a similar refolding condition. It is apparent that not only the refolding protocol consisting of $0.8 \mathrm{M}$ arginine but also the C12-L-Glu concentration must be optimized for refolding of the HyHEL-10 scFv. Refolding yield gradually increased with C12-L-Glu concentration, reaching $\sim 100 \%$ at or above $0.15 \%$ C12-L-Glu. It is interesting that the refolding yield was still 100\% above the CMC (0.3\%), meaning that C12-L-Glu is effective during refolding even in the micelle form. This however assumes that C12-L-Glu micelles are stable in the presence of $0.8 \mathrm{M}$ arginine: it is highly likely that arginine disrupts the micelle structure, based on the observation that arginbine inhibits fatty acid aggregation [72]. The observed enhanced refolding by C12-L-Glu suggests binding of C12-L-Glu to the protein, which may increase the solubility of the protein (inhibit protein aggregation) or alter the structure to the one more competent for folding. The observed enhancement above CMC suggests either that C12-L-Glu binding to the protein in micelle form does not lead to the $\mathrm{scFv}$ structure incompetent for folding or that the detergent binding is molecular even above $\mathrm{CMC}$, as the micellar structure may be disrupted by $0.8 \mathrm{M}$ arginine. It should be noted in Figure 8 that the greater than $100 \%$ yield is within experimental errors of protein analysis.

The above refolding was done in the presence of $1 \mathrm{mM}$ oxidized and reduced glutathione. This ratio was determined by observing formation of oxidized band on non-reducing SDS-PAGE. When the ratio of GSSG to GSH was varied from 1:5 mM to $3: 1 \mathrm{mM}$, the 1:1 mM ratio gave the best result. 
Figure 7. General refolding protocol for scFv with C12-L-Glu.

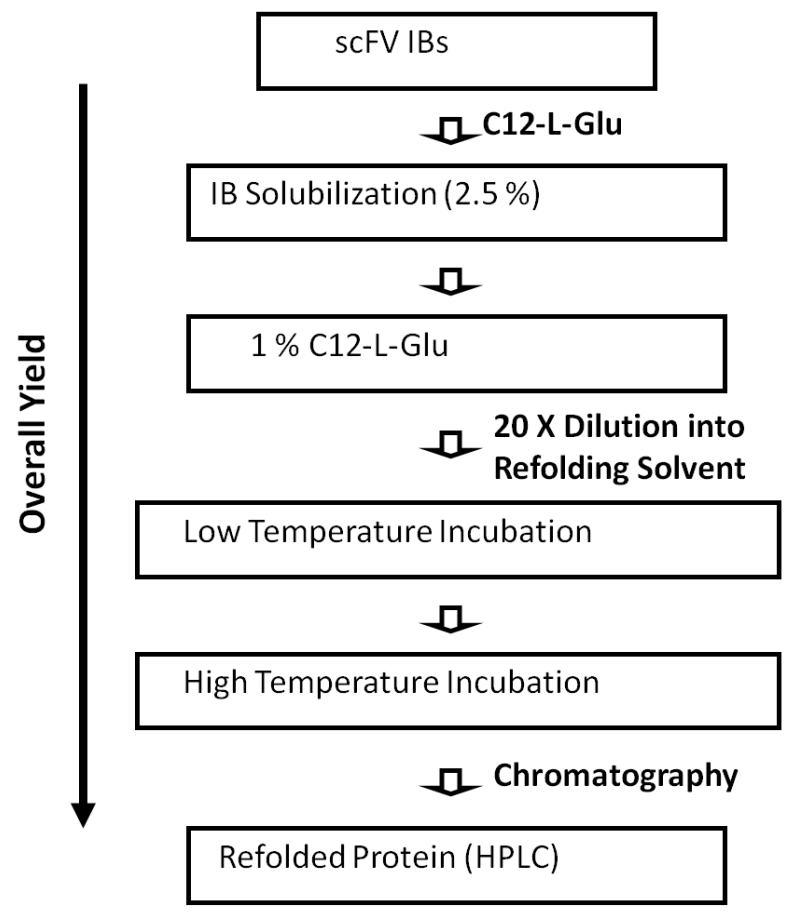

Figure 8. Refolding of HyHEL-10 scFv in the presence of $0.8 \mathrm{M}$ arginine as a function of C12-L-Glu concentration.

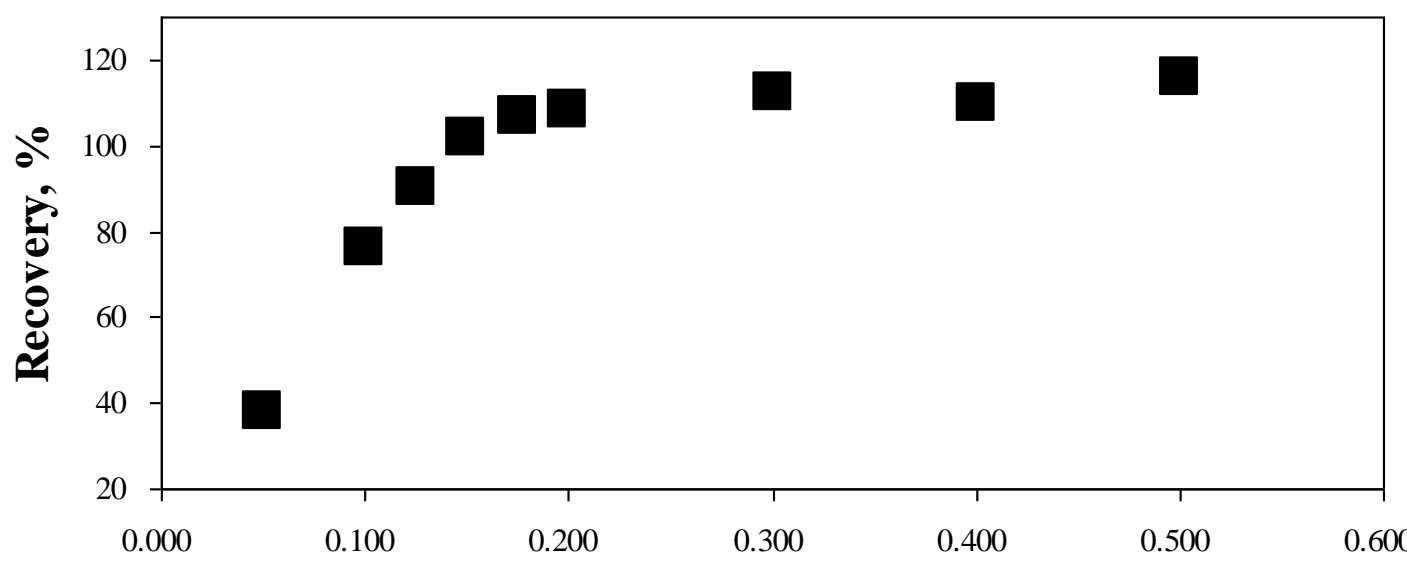

C12-L-Glu, \%

Another $\mathrm{scFv}$ construct, i.e., anti-fluorescein $\mathrm{scFv}$, was derived from a monoclonal antibody against a fluorescent probe, fluorescein. This antibody stoichiometrically binds to the antigen with high affinity and abolishes fluorescence from this fluorophore. Anti-fluorescein scFv IBs were solubilized with $2.5 \%$ C12-L-Glu, $\mathrm{pH} 8.5$, at $15 \mathrm{mg} \mathrm{IB} / \mathrm{mL}$, containing $8 \mathrm{mg}$ anti-fluorescein $\mathrm{scFv} / \mathrm{mL}$. After rounds of screenings based on the scheme of Figure 7, it was apparent that without optimization, the refolding yield would be extremely low. Thus, an experiment was done to determine optimal concentrations of arginine and C12-L-Glu. The $2.5 \%$ C12-L-Glu solubilized IBs were diluted to $1 \%$ detergent as in the case for HyHEL-10 scFv. This was then 10-fold diluted to the solutions containing $0-0.8 \mathrm{M}$ arginine and $0.05 \%-0.4 \% \mathrm{C} 12-\mathrm{L}-\mathrm{Glu}$ as indicated in Figure 9. The diluted samples were incubated first at $10{ }^{\circ} \mathrm{C}$ for $17 \mathrm{~h}$ and then at $23{ }^{\circ} \mathrm{C}$ for $12 \mathrm{~h}$. The recovery from this refolding is plotted 
in Figure 9 as a function of both arginine and C12-L-Glu concentrations. In the absence of arginine, recovery of folded $\mathrm{scFv}$ was undetectable at $0.05 \% \mathrm{C} 12-\mathrm{L}-\mathrm{Glu}$ (white bar), most likely due to insufficient solubility of this $\mathrm{scFv}$ during refolding. However, at $0.05 \% \mathrm{C} 12$-L-Glu, addition of arginine at 0.4 and $0.8 \mathrm{M}$, in particular the latter, greatly increased the refolding (white bar). Nevertheless, the yield was below $10 \%$ even at $0.8 \mathrm{M}$ arginine. In the presence of $0.2 \% \mathrm{C} 12-\mathrm{L}-\mathrm{Glu}$ (gray bar), the recovery was already high even without arginine ( $~ 8 \%)$. The addition of $0.4 \mathrm{M}$ arginine increased the yield to over $15 \%$. The addition of $0.8 \mathrm{M}$ arginine further increased the yield to $\sim 20 \%$. Arginine and C12-L-Glu enhanced refolding synergistically, as $0.4 \%$ C12-L-Glu (black bar) along with $0.4 \mathrm{M}$ arginine further enhanced refolding. It is evident that $0.8 \mathrm{M}$ arginine and 0.2-0.4 M C12-L-Glu led to the highest recovery under the experimental conditions used. As in HyHEL-10 scFv, two-step incubation enhanced refolding, suggesting that refolding of the anti-fluorescein scFv also occurs in multiple steps. More detailed analysis of the effects of C12-L-Glu concentration showed that $0.3 \%$ may be most suitable for refolding of the anti-fluorescein $\mathrm{scFv}$. When the second incubation temperature was raised to $45^{\circ} \mathrm{C}$, over $20 \%$ yield was obtained.

Figure 9. Refolding of anti-fluorescein $\mathrm{scFv}$ as a function of $\mathrm{C} 12-\mathrm{L}-\mathrm{Glu}$ and arginine concentrations. White bar, 0.05\% C12-L-Glu. Gray bar, 0.2\% C12-L-Glu. Black bar, 0.4\% C12-L-Glu.

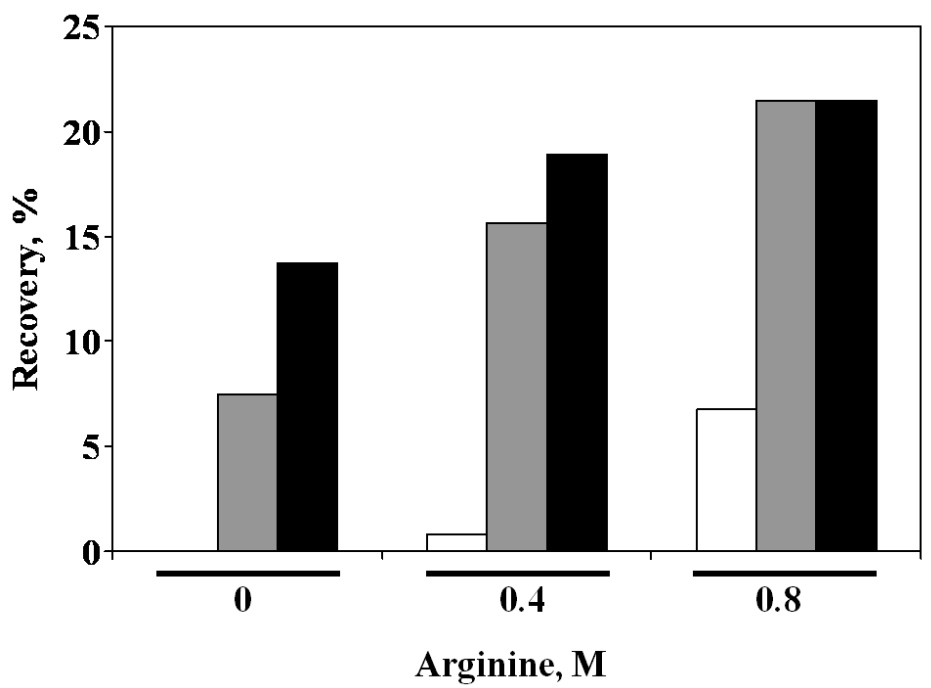

The effects of the first incubation temperature were then examined at the fixed second incubation of $45^{\circ} \mathrm{C}$ and $4 \mathrm{~h}$. The first incubation temperature was varied at 5,10 and $15{ }^{\circ} \mathrm{C}$ with an incubation time of $18.5 \mathrm{~h}$ : refolding conditions were $0.1 \%$ C12-L-Glu, $0.8 \mathrm{M}$ arginine and $1 \mathrm{mM}$ GSSG/1 mM GSH. The C12-L-Glu concentration used is lower than the above optimal concentration. As shown in Figure 10A, the recovery after first incubation increased with the incubation temperature, but was only slightly above $15 \%$ at $15{ }^{\circ} \mathrm{C}$ incubation (black bar). When the incubation temperature, after the first low temperature incubation, was raised to $45{ }^{\circ} \mathrm{C}$, the recovery increased for all three first incubation temperatures. For the $15{ }^{\circ} \mathrm{C}$ incubation condition, the recovery was greater that $25 \%$ after $4 \mathrm{~h} 45^{\circ} \mathrm{C}$ incubation (black bar, second column). This result clearly indicates that the refolding occurs via multiple steps and higher temperature at the first incubation facilitates refolding. Such stepwise increase in refolding temperature was more effective when done in three steps. Between the first low 
temperature incubation and the second $45{ }^{\circ} \mathrm{C}$ incubation, $23{ }^{\circ} \mathrm{C}$ incubation for $24 \mathrm{~h}$ was inserted. The results are shown in Figure 10B. As in the left panel, the diluted samples were first incubated at three temperatures as plotted in the first three columns in Figure $10 \mathrm{~B}$. The intermediate $23{ }^{\circ} \mathrm{C}$ incubation greatly enhanced refolding for all three temperatures, e.g., reaching over $30 \%$ when the $15{ }^{\circ} \mathrm{C}$ incubated sample (black bar) was followed by $23{ }^{\circ} \mathrm{C}$ incubation. When the intermediate incubation was followed by $45{ }^{\circ} \mathrm{C}$ incubation, recovery further increased for all three temperatures. Among them, the $10{ }^{\circ} \mathrm{C}$ incubated sample (gray bar) resulted in the highest yield after $25{ }^{\circ} \mathrm{C}$ and subsequent $45^{\circ} \mathrm{C}$ incubation. It appears that the presumed multi-step folding of $\mathrm{scFv}$ was facilitated by an incremental increase in incubation temperature.

Figure 10. Effect of incubation temperature on refolding of $\mathrm{scFv}$. Initial incubation temperature: white bar, $5{ }^{\circ} \mathrm{C}$; gray bar, $10{ }^{\circ} \mathrm{C}$; black bar, $15^{\circ} \mathrm{C}$.
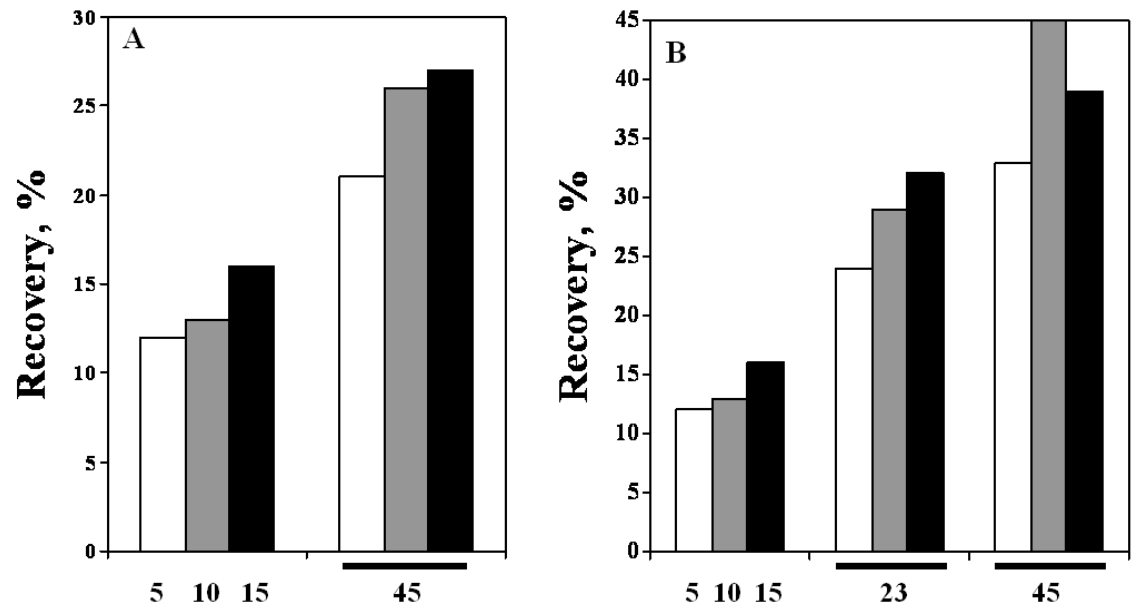

Incubation Temperature, ${ }^{\circ} \mathrm{C}$

It is interesting that incremental change in refolding temperature enhances refolding yield. Such enhanced refolding of $\mathrm{scFv}$ was also observed during stepwise dialysis, where denaturant concentration was incrementally reduced [43]. The construct of scFv consists of two domains linked by a short spacer sequence, i.e., heavy chain variable domain, linker and light chain variable domain, as shown schematically in Figure 11. Each domain has a disulfide bond that should stabilize the domain structure. The most likely mechanism may be stepwise folding: i.e., formation of intermediate structures followed by the formation of the native structure. Based on the temperature effects on recovery, it may be concluded that low temperature is favored in formation of the intermediate structures without formation of off-pathway products (such as incorrect SS bonds or aggregation) and high temperature accelerates the conversion of the intermediate to native structure with correct domain-domain interactions. This stepwise folding protocol by modulating incubation temperature may also be applicable to other refolding processes, such as solubilization by denaturants or other detergents. In this regard, the stepwise dialysis refolding gave a high yield of $\mathrm{scFv}$ [43]. Concentrations of denaturant and refolding-assisting agents were modulated stepwise, which can be similarly explained from the presence of folding intermediates. Earlier step containing high denaturant concentration favors formation of the intermediate structures, while preventing the off-pathway 
product formation. The subsequent drop in denaturant concentration facilitates the formation of the final product. In either case, arginine may serve as an aggregation suppressor.

Figure 11. Schematic illustration of folding course of scFv. Two black curves express two variable domains (I and II). Gray line is a linker connecting two domains.

Aggregates
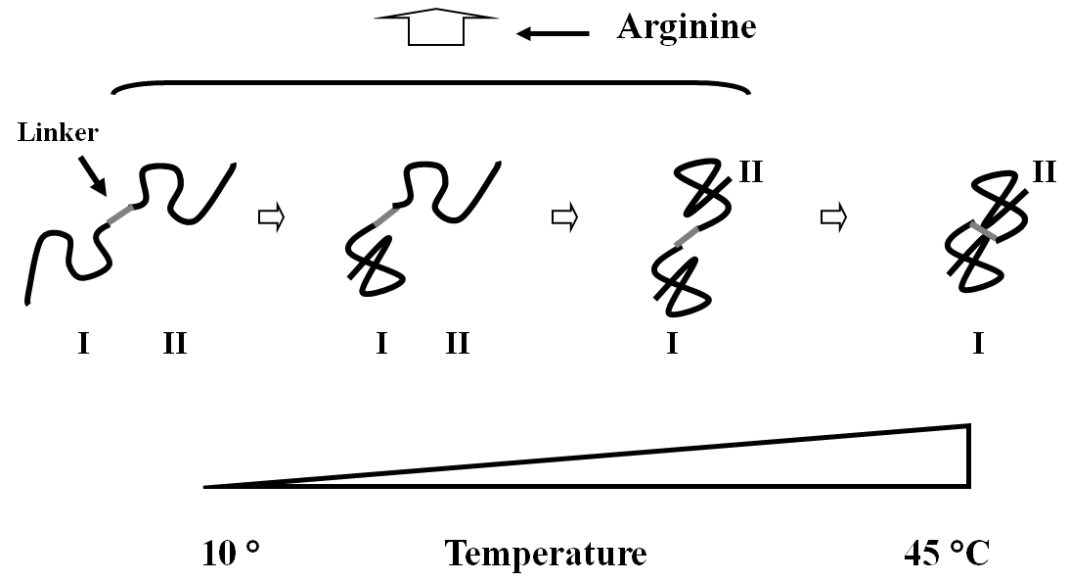

\section{Property of C12-L-Glu}

To our knowledge, only available data with regard to the physical properties of C12-L-Glu is a systematic study by Xia et al. [47]. The solution properties of lauroyl-amino acids have been analyzed based on the transfer free energy concept developed by Nozaki and Tanford [73-76] and later extended by Gekko's group [77,78], Liu and Bolen [79] and Arakawa and Timasheff [80-82]. Tanford [83] determined the hydrophobic properties of amino acid side chains by measuring the solubility of amino acids and glycine in water and ethanol. The transfer free energy was then calculated from the differences in solubility between water and ethanol. Ethanol was chosen as a hydrophobic, non-polar solvent. When the solubility of an amino acid decreases in ethanol compared to the aqueous solubility, the transfer free energy is positive, indicating that the amino acid favors water over ethanol. All natural amino acids prefer water to ethanol due to the charged amino and carboxyl groups, whose electrostatic free energy is stabilized in polar solvents, e.g., water. This charge contribution can be approximately estimated from the transfer free energy of glycine that lacks the side chain. Thus, the transfer free energy of side chain can be estimated from the difference between amino acids and glycine, as shown in Equation 1.

$$
\Delta \mathrm{G}_{\mathrm{SC}}=\Delta \mathrm{G}_{\mathrm{AA}}-\Delta \mathrm{G}_{\mathrm{G}}
$$

In Equation $1, \Delta \mathrm{G}$ is the transfer free energy of an amino acid from water to ethanol and the subscript SC, AA and G are the side chain, amino acid and glycine. Thus, the transfer free energy of the side chain, $\Delta \mathrm{G}_{\mathrm{SC}}$ is the difference in transfer free energy between each amino acid and glycine. The value for glycine exceeds the values for other amino acids. This means that the transfer free energy of these chains from water to ethanol is negative: these side chains are stabilized by ethanol. Thus, the more negative the transfer free energy for a particular side chain, the more hydrophobic the side chain 
is. They compared the CMC of various lauroyl-amino acids using the transfer free energy of the amino acid side chain of these lauroyl-amino acids.

$\mathrm{Na}$ (monosodium) salts of $N$-lauroyl amino acids with 5 different amino acids (Gly, Glu, Ala, Val and Phe in increasing hydrophobicity) showed decreasing CMC in this order, ranging $16 \mathrm{mM}$ for C12-Gly and $3 \mathrm{mM}$ for C12-L-Phe.The transfer free energy of these side chains from water to ethanol is more negative and their side chain is more hydrophobic in this order. Thus, hydrophobic side chains stabilize the micelles (lowering CMC). These $N$-lauroyl-amino acids all decreased the surface tension of water, with the magnitude in the reverse order: i.e., the surface tension increased in the order of Gly < Glu < Ala < Val < Phe < pure water. In this regard, C12-L-Glu is fairly strong in suppressing the surface tension of water, but requires high concentration for micelle formation (high CMC at $13 \mathrm{mM}$ ). It is not clear from these properties why C12-L-Glu is special in protein refolding. Xia et al. [47] compared these $N$-lauroyl-amino acids at $0.25 \%$ (below CMC) in terms of the detergency, foaming power and emulsifying power. The parameter detergency is the ability of the surfactants to wash off stains, e.g., blood or grease, from a given surface. This parameter increased in the order of Gly $<$ Ala $<$ Val $<$ Phe. C12-L-Glu was exceptionally weak in this property. At this concentration (0.25\%), both C12-Gly and C12-L-Glu are below CMC, thus indicating that the molecular C12-L-Glu is weak in dissolving these stains. The observed weak detergency of C12-L-Glu below CMC may be closely related to its critical property during refolding: i.e., it readily dissociates from the folded proteins. The foaming power of C12-L-Glu is exceptionally strong, indicating its ability to stabilize the foams. The foaming power of C12-L-Glu is well above the other four amino acids, i.e., stronger than anticipated from its side chain hydrophobicity. This may be explained in terms of the effectiveness of C12-L-Glu to suppress the surface tension of water. In this regard, C12-Gly is far weak in stabilizing the foams, despite its effectiveness as a surface tension depressant. Such strong effect of C12-L-Glu on the surface tension of water may be related to the two carboxyl groups, resulting in strong hydration potential of the side chains and in turn stabilizing the water/foam interface. C12-L-Glu at $0.25 \%$ is also unique in emulsifying power, which is a measure of mixing oil and water. C12-L-Glu is exceptionally effective in stabilizing the interface between oil and water, leading to the effective mixing. Both the foaming and emulsifying powers of C12-L-Glu may be at least in part due to its ability to suppress the surface tension of water. It is, however, much better than C12-Gly that has a lower surface tension than C12-L-Glu, indicating uniqueness of Glu. While effectively stabilizing the interface, C12-L-Glu at $0.25 \%$ cannot dissolve the stains, which may be related to its weak hydrophobic nature and hence binding to the stains.

It is expected that these properties of C12-L-Glu depend on the charged states of 2 carboxyl groups. The surface tension sharply increases with titration of two carboxyl groups at higher $\mathrm{pH}$ (i.e., $\mathrm{COOH}$ $\rightarrow \mathrm{COO}^{-}$). Interestingly, the foaming power increases with titration from 1.0 to 1.6 carboxyl groups, above which this property sharply decreases. At about 1.6 carboxylate groups $\left(-\mathrm{COO}^{-}\right)$, it most effectively stabilized the foams. However, the emulsifying power decreases with titration above 1.2. The aggregation number of C12-L-Glu micelles is about 80 ( 80 molecules per micelle on average) up to 1.4 carboxylates, above which the aggregation number sharply increases, reaching 110 at 2.0 titration of carboxyl groups. Such an increase in aggregation number was ascribed to loose packing of two carboxylated C12-L-Glu to form large micelles.

Lower detergency of C12-L-Glu described above may be related to its weaker cytotoxicity, denaturation potential and hemolytic activity [47]. It showed low cytotoxicity to cultured human skin 
cells. When the concentration of $\mathrm{C} 12$-amino acids required for $50 \%$ denaturation of $\mathrm{Cu}_{2}$-transferine or $50 \%$ hemolysis was plotted against hydrophobicity, the value for C12-L-Glu derived from the linear correlation was $0.8 \mathrm{mM}$ for hemolysis and $4 \mathrm{mM}$ for $\mathrm{Cu}_{2}$-transferine denaturation: i.e., $50 \%$ $\mathrm{Cu}_{2}$-transferine would be denatured at $4 \mathrm{mM}$ and $50 \%$ hemoglobin would be lysed at $0.8 \mathrm{mM}$. The observed concentrations for C12-L-Glu were much higher, $20 \mathrm{mM}$ (25-fold) for hemolytic activity and $13 \mathrm{mM}$ (3-fold) for protein denaturation. These less toxicity may be due to its weaker interaction with the protein or other target molecules, as has been seen in its weaker detergency. Such properties may be important for protein refolding, as it may more readily dissociate from the proteins. Such ability to dissociate may also assist removal of residual detergents from the final product. In addition, less toxicity may give an advantage as a safer refolding agent.

Dissociation of C12-L-Glu from proteins was experimentally confirmed using model proteins [45]. C12-L-Glu at $2 \%$ denatured both bovine serum albumin (BSA) and IL-6. When the detergent concentration was reduced to $0.1 \%$, the native protein structure was regained, suggesting that the bound detergent molecules have dissociated. Native gel analysis showed an identical mobility of BSA and IL- 6 when these protein samples containing 0, 0.1 and 0.2\% C12-L-Glu were loaded on the native gel, indicating that the proteins are not binding the detergent during electrophoresis.

\section{Effects of Arginine on Refolding}

Because of its natural presence as a cell metabolite and hence safety [84], arginine is now widely used in biotechnology field. It is used in refolding proteins [50-65], suppressing aggregation of pharmaceutical proteins during formulation [85,86], enhancing elution and minimizing aggregation during column chromatography [87,88], and solubilization of proteins from inclusion bodies [89,90] and virus inactivation [91-99]. It also increases the solubility of various low molecular weight organic compounds [100-103]. Because of its unique effects, there is a strong interest in understanding why arginine is so effective in these applications. Relatively high concentrations are required in most of the above applications. Requirement of high concentration is a reflection of weak interactions of arginine with proteins or other target molecules and its indirect effect on proteins or others through weak binding to water molecules. When solvent additives, such as arginine, are only effective at high concentrations, they are called "co-solvents" to indicate that they are a part of the solvent. One technique that has been used to study the mechanism of co-solvent effects is equilibrium dialysis. This technique was extensively used to study the effects of co-solvents listed in Table 1. In early 1980, there were strong interests in understanding the mode of interactions of amino acids with proteins, as certain amino acids have been shown to stabilize proteins [66]. Stabilizing effects of other co-solvents, including sugars, polyhydric alcohols and certain salts, were found to correlate with their exclusion from the protein surface [104-108]. When arginine was compared with protein-stabilizing amino acids, it showed clear indication that arginine is different from the stabilizing amino acids in terms of its interaction with the proteins [109]. 
Table 1. Mode of preferential interaction of proteins with various co-solvents.

\begin{tabular}{lll}
\hline Co-solvent & Interaction with Protein & Effects on Protein \\
\hline Denaturants (Urea, GdnHCl) & Binding & Denaturation/Salting-in \\
Organic solvents & Exclusion & Precipitation \\
& Binding & Denaturation \\
Sugars/Polyols & Exclusion & Stabilization \\
Salts & Exclusion & Stabilization/Salting-out \\
& Binding & Salting-in \\
Polymers & Exclusion & Precipitation \\
Amino Acids & Exclusion & Stabilization \\
Arginine & & Aggregation Suppression \\
\hline
\end{tabular}

The interaction of co-solvents with proteins can be studied by thermodynamic techniques, e.g., equilibrium dialysis. Such thermodynamic measurements give a parameter, termed "preferential interaction", which indicates preference of protein surface for co-solvent or water, as depicted in Figure 12. Preferential interaction measurements have resulted in the wealth of information, as summarized in Table 1, with regard to the denaturing effects of guanidine hydrochloride (GdnHCl) [110], urea [111-113] and organic solvents [80,114-119], the stabilizing effects of polyols [104,106], sugars [105,107], salting-out salts [81,108] and osmolytic amino acids [120-122] and the precipitating effects or salting-in effects of certain organic solvents and salts [81,108,123-126]. As summarized in Table 1, there is a clear distinction between denaturants and stabilizers or between precipitants and salting-in co-solvents. Figure 12A depicts the preferential binding of protein denaturants and salting-in agents. They (shown by closed triangles) preferentially bind to the protein surface. Protein-protein interaction and hence aggregation reduce such binding and hence is disfavored by these co-solvents, as such reactions would reduce co-solvent bindings. On the contrary, preferential exclusion of co-solvents has been universally observed for protein stabilizers [81,104-108,120,122]. Such case is depicted in Figure $12 \mathrm{C}$, where their preferential exclusion leads to the thermodynamically unstable solution, which is reduced by protein aggregation (see Figure 12C for dotted line). They thus enhance protein-protein interactions. Arginine showed unique interactions with BSA and lysozyme [109] and other proteins [127], different from their interactions with protein-stabilizing amino acids. Weak binding of arginine to the proteins was implicated (Figure 12B): binding is intermediate between stabilizing and denaturing co-solvents. So a question is how binding of arginine to proteins is related to its effect on protein refolding. The way arginine interacts with the native proteins has been studied by different techniques. Contact of arginine with aromatic groups was shown in crystal structure analysis of lysozyme [128] and by molecular dynamics simulation [100,129]. Such binding of arginine to aromatic groups was also shown with small aromatic compounds [100-102,130]. Binding of arginine with aromatic groups is at least in part mediated by the side chain of arginine, as the guanidinium-aromatic interactions are frequently observed in the folded protein structures [131-134]. Conversely, no 
apparent binding of arginine in the lysozyme crystal was also observed, perhaps due to different crystallization conditions [135]. However, it showed changes in hydration of the lysozyme [135]. Different observation for arginine binding in lysozyme crystals suggests that arginine binding may not be strong and thus is readily affected by crystallization condition. Such weak binding and hydration change may be consistent with the following preferential interaction analysis. Although these data suggest potential binding of arginine to the native protein surface, other types of interaction can occur in aqueous arginine solution. The effects of arginine on protein aggregation are determined by overall interactions, not just by specific site bindings, of arginine with the protein surface. Such overall interactions involve hydration of both arginine and protein and arginine-protein interaction.

Figure 12. Different mode of interactions between co-solvent and protein. (A) denaturants. (B) arginine. (C) stabilizers. Upper panels show the interaction, while the lower panels show how protein-protein interaction affects co-solvent interaction at the protein-protein contact.
A. Preferential Binding
B. Neutral
C. Preferential Exclusion

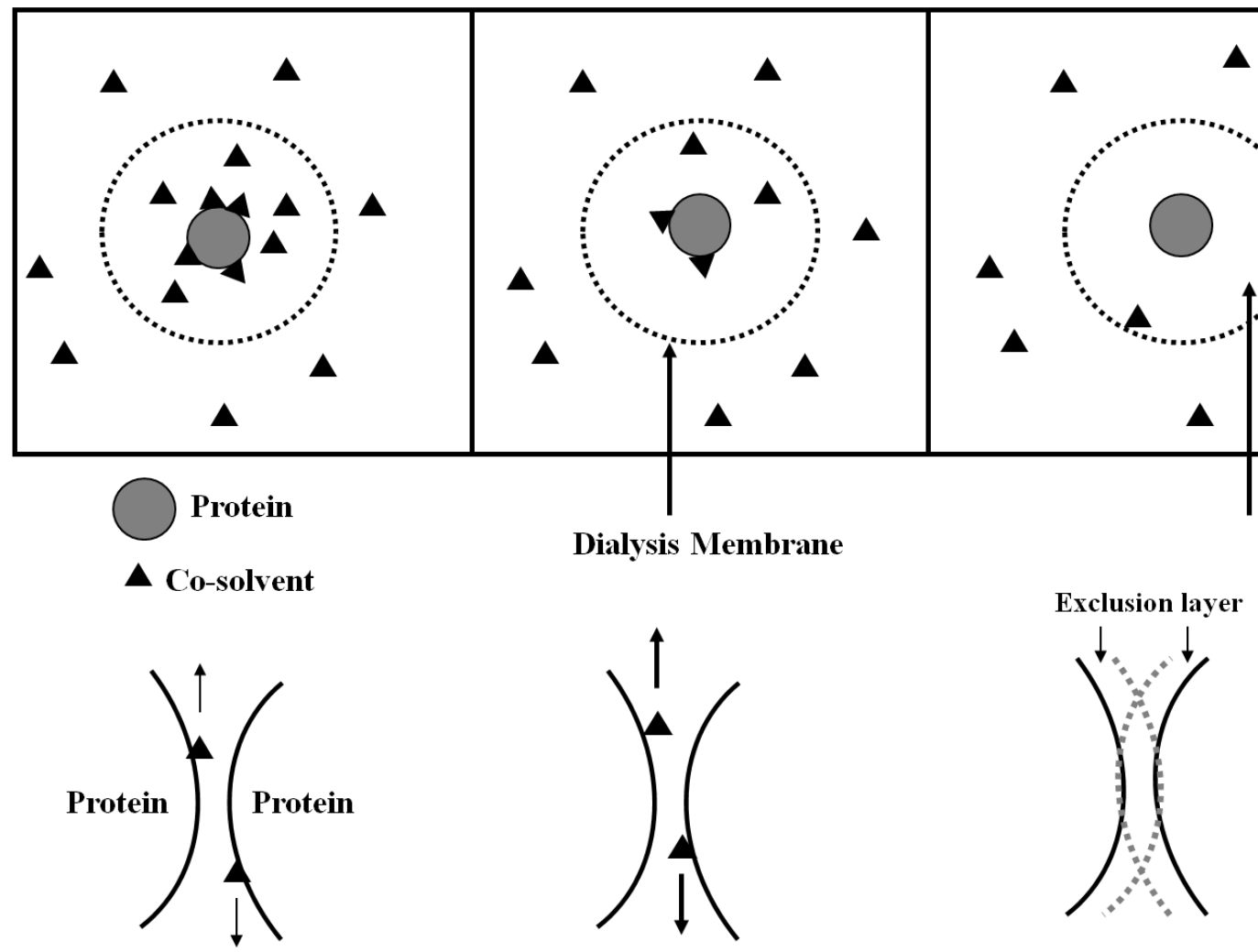

It has been shown that many protein-protein interactions involve aromatic interactions and hence the affinity of arginine for aromatic groups can disrupt such aromatic interactions and enhance dissociation even when the overall interaction with the protein surface is of exclusion. When protein-protein interaction is also supported by electrostatic interactions, arginine can disrupt such interaction, also due its ionic property. If the protein-protein interaction is supported by hydrophobic interaction through alkyl groups, however, the effects of arginine might not be toward dissociation. At this stage, we really do not have a good understanding of the effects of arginine on pure hydrophobic interaction. 
The effects of arginine on kinetics of protein-protein interaction were extensively analyzed by Trout's group. They called the effects of arginine, the "gap effect" [136]. It is similar to the effects of denaturants on protein-protein interaction. However, the larger size of arginine than many denaturants means that there will be many water molecules left bound when two protein molecules approach each other and remove bound arginine from the contact area (see Figure 12B, lower panel), leading to a highly unfavorable energy state toward association and an enhanced activation energy. This argument again requires that arginine be involved in the contact areas of associating proteins.

The mechanism of arginine on aggregation suppression during refolding or unfolding has been suggested to be due to its effects on intermediate structures [51,137,138]. It is an established concept that both refolding and unfolding reactions do not occur in one step, i.e., from unfolded to native and native to unfolded, but rather go through structure intermediates, in which some secondary structures are formed, but the tertiary structure is still largely unfolded. Both unfolding and refolding reactions are often made irreversible due to aggregation of the structure intermediates. Arginine has been suggested to increase the solubility of the intermediate structures and suppress their aggregation [56,136,137]. How effective arginine is against aggregation during refolding or unfolding may depend on the structure of the intermediates. If a large portion of aromatic side chains is present in a protein molecule and exposed in the intermediate structures, then arginine may be highly effective in aggregation suppression.

\section{References}

1. Yamada, T. Therapeutic monoclonal antibodies. Keio J. Med. 2011, 60, 37-46.

2. Jenkins, N.; Meleady, P.; Tyther, R.; Murphy, L. Strategies for analysing and improving the expression and quality of recombinant proteins made in mammalian cells. Biotechnol. Appl. Biochem. 2009, 53, 18-25.

3. Shukla, A.A.; Thommes, J. Recent advances in large-scale production of monoclonal antibodies and related proteins. Trends Biotechnol. 2010, 28, 253-261.

4. Shukla, A.A.; Hubbard, B.; Tressel, T.; Guhan, S.; Low, D. Downstream processing of monoclonal antibodies-application of platform approaches. J. Chromatogr. B Analyt. Technol. Biomed. Life Sci. 2007, 848, 28-39.

5. Low, D.; O'Leary, R.; Pujar, N.S. Future of antibody purification. J. Chromatogr. B Analyt. Technol. Biomed. Life Sci. 2007, 848, 48-63.

6. Chon, J.H.; Zarbis-Papastoitsis, G. Advances in the production and downstream processing of antibodies. N. Biotechnol. 2011, 28, 458-463.

7. Beck, A.; Wurch, T.; Bailly, C.; Corvaia, N. Challenges for the next generation of therapeutic antibodies. Nat. Rev. Immunol. 2010, 10, 345-352.

8. Demarest, S.J.; Glaser, S.M. Antibody therapeutics, antibody engineering, and the merits of protein stability. Curr. Opin. Drug Dev. 2008, 11, 675-687.

9. Kontermann, R.E. Alternative antibody formats. Curr. Opin. Mol. Ther. 2010, 12, 176-183.

10. Moffat, F.L.J.; Gulec, S.A.; Serafini, A.N.; Sfakianakis, G.N.; Pop, R.; Robinson, D.S.; Franceschi, D.; Boggs, J.; Livingstone, A.S. A thousand points of light and just dim bulbs? Radiolabeled antibodies and colorectal cancer imaging. Cancer Invest. 1999, 17, 322-334. 
11. Colcher, D.; Goel, A.; Pavlinkova, G.; Beresford, G.; Booth, B.; Batra, S.K. Effects of genetic engineering on the pharmacokinetics of antibodies. Q. J. Nucl. Med. 1999, 43, 132-139.

12. Nelson, A.L.; Reichert, J.M. Development trends for therapeutic antibody fragments. N. Biotechnol. 2009, 27, 331-337.

13. Yazaki, P.J.; Shively, L.; Clark, C.; Cheung, C.-W.; Le, W.; Szpikowska, B.; Shively, J.E.; Raubitschek, A.A.; Wu, A.M. Mammalian expression and hollow fiber biorector production of recombinant anti-CEA diabody and minibody for clinical applications. J. Immunol. Methods 2001, 253, 195-208.

14. Accardi, L.; Di Bonito, P. Antibodies in single-chain format against tumour-associated antigens: Present and future applications. Curr. Med. Chem. 2010, 17, 1730-1755.

15. Wörn, A.; Plückthun, A. Stability engineering of antibody single-chain Fv fragments. J. Mol. Biol. 2001, 305, 989-1010.

16. Stockwin, L.H.; Holmes, S. The role of therapeutic antibodies in drug discovery. Biochem. Soc. Trans. 2003, 31, 433-436.

17. Liu, Y.; Liu, Y.; Mernaugh, R.L.; Zeng, X. Single chain fragment variable recombinant antibody functionalized gold nanoparticles for a highly sensitive colorimetric immunoassay. Biosens. Bioelectron. 2009, 24, 2853-2867.

18. Schmidt, S.R. Fusion-proteins as biopharmaceuticals-applications and challenges. Curr. Opin. Drug Discov. Dev. 2009, 12, 284-295.

19. Makabe, K.; Asano, R.; Ito, T.; Tsumoto, K.; Kudo, T.; Kumagai, I. Tumorpdirected lymphocyte-activating cytokines: Refolding-based preparation of recombinant human interleukin-12 and an antibody variable domain-fused protein by additive-introduced stepwise dialysis. Biochem. Biophys. Res. Commun. 2005, 328, 98-105.

20. Sharkey, R.M.; Goldenberg, D.M. Perspective on cancer therapy with radiolabeled monoclonal antibodies. J. Nucl. Med. 2005, 46, 115S-127S.

21. Kelly, M.P.; Lee, F.T.; Tahtis, K.; Power, B.E.; Smyth, F.E.; Brechbiel, M.W.; Hudson, P.J.; Scott, A.M. Tumor targeting by a multivalent single-chain Fv (scFv) anti-Lewis Y Antibody construct. Cancer Biother. Radiopharm. 2008, 23, 411-423.

22. Beckman, R.A.; Weiner, L.M.; Davis, H.M. Antibody constructs in cancer therapy: Protein engineering strategies to improve exposure in solid tumors. Cancer 2007, 109, 170-179.

23. Ottiger, M.; Thiel, M.A.; Feige, U.; Lichtlen, P.; Urech, D.M. Efficient intracocular penetration of topical anti-TNF- $\alpha$ single-chain antibody (ESBA105) to anterior and posterior segment without penetration enhancer. Invest. Ophthal. Vis. Sci. 2009, 50, 779-786.

24. Wittel, U.A.; Jain, M.; Goel, A.; Chauhan, S.C.; Colcher, D.; Batra, S.K. The in vivo characteristics of genetically engineered divalent and tetravalent single-chain antibody constructs. Nucl. Med. Biol. 2005, 32, 157-164.

25. Kirschning, C.J.; Dreher, S.; Maass, B.; Fichte, S.; Schade, J.; Köster, M.; Noack, A.; Lindenmaier, W.; Wagner, H.; Böldicke, T. Generation of anti-TLR2 intrabody mediating inhibition of macrophage surface TLR2 expression and TLR2-driven cell activation. BMC Biotechnol. 2010, 10, 31 . 
26. Xiong, H.; Li, S.; Yang, Z.; Burgess, R.R.; Dynan, W.S. E. coli expression of a soluble, active single-chain antibody variable fragment containing a nuclear localization signal. Protein Expr. Purif. 2009, 66, 172-180.

27. Poul, M.A. Selection of antibodies able to rapidly enter mammalian cells. Methods Mol. Biol. 2009, 562, 155-163.

28. Butler, D.C.; McLear, J.A.; Messer, A. Engineered antibody therapies to counteract mutant huntingtin and related toxic intracellular proteins. Prog. Neurobiol. 2012, 97, 190-204.

29. Hasegawa, H.; Wendling, J.; He, F.; Trilisky, E.; Stevenson, R.; Franey, H.; Kinderman, F.; Li, G.; Piedmonte, D.M.; Oslund, T.; Shen, M.; Ketchem, R.R. In vivo crystallization of human IgG in the endoplasmic reticulum of engineered CHO cell. J. Biol. Chem. 2011, 286, 19917-19931.

30. Wurm, F.M. Production of recombinant protein therapeutics in cultivated mammalian cells. N. Biotechnol. 2004, 22, 1393-1398.

31. Humphreys, D.P.; Glover, D.J. Therapeutic antibody production technologies: Molecules, applications, expression and purification. Curr. Opin. Drug Dev. 2001, 4, 172-185.

32. Andersen, D.C.; Reilly, D.E. Production technologies for monoclonal antibodies and their fragments. Curr. Opin. Biotechnol. 2004, 15, 456-462.

33. Arbabi-Ghahroudi, M.; Tanha, J.; MacKenzie, R. Prokaryotic expression of antibodies. Cancer Metastasis Rev. 2005, 24, 501-519.

34. Sun, W.; Xie, J.; Lin, H.; Mi, S.; Li, Z.; Hua, F.; Hu, Z. A combined strategy improves the solubility of aggregation-prone single-chain variable fragment antibodies. Protein Expr. Purif. 2012, 83, 21-29.

35. Lilie, H.; Schwarz, E.; Rudolph, R. Advances in refolding of proteins produced in E. coli. Curr. Opin. Biotechnol. 1998, 9, 497-501.

36. Tsumoto, K.; Ejima, D.; Kumagai, I.; Arakawa, T. Practical consideration in refolding proteins from inclusion bodies. Protein Expr. Purif. 2003, 28, 1-8.

37. Zardeneta, G.; Horowits, P.M. Detergent, liposome, and micelle-assisted protein refolding. Anal. Biochem. 1994, 223, 1-6.

38. Zardeneta, G.; Horowitz, P.M. Protein refolding at high concentrations using detergent/phospholipid mixtures. Anal. Biochem. 1994, 218, 392-398.

39. Michaux, C.; Pomroy, N.C.; Privè, G.G. Refolding SDS-denatured proteins by the addition of amphipathic cosolvents. J. Mol. Biol. 2008, 375, 1477-1488.

40. Lu, H.; Clogston, C.L.; Narhi, L.O.; Merewether, L.A.; Pearl, W.R.; Boone, T.C. Folding and oxidation of recombinant human granulocyte colony stimulating factor produced in Escherichia coli. Characterization of the disulfide-reduced intermediates and cysteine-serine analogs. J. Biol. Chem. 1992, 267, 8770-8777.

41. Kurucz, I.; Titus, J.A.; Jost, C.R.; Segal, D.M. Correct disulfide pairing and efficient refolding of detergent-solubilized single-chain Fv proteins from bacterial inclusion bodies. Mol. Immunol. 1995, 32, 1443-1452.

42. Fursova, K.K.; Laman, A.G.; Melnik, B.S.; Semisotnov, G.V.; Kopylov, P.K.; Kiseleva, N.V.; Nesmeyanov, V.A.; Brovko, F.A. Refolding of scFv mini-antibodies using size-exclusion chromatography via arginine solution layer. J. Chromatogr. B 2009, 877, 2045-2051. 
43. Tsumoto, K.; Shinoki, K.; Kondo, H.; Uchikawa, M.; Juji, T.; Kumagai, I. Highly efficient recovery of functional single-chain $\mathrm{Fv}$ fragments from inclusion bodies overexpressed in Escherichia coli by controlled introduction of oxidizing reagents-application to a human single-chain Fv fragment. J. Immunol. Methods 1998, 219, 119-129.

44. Fujii, T.; Ohkuri, T.; Onodera, R.; Ueda, T. Stable supply of large amounts of human Fab from the inclusion bodies in E. coli. J. Biochem. 2007, 141, 699-707.

45. Kudou, M.; Yumioka, R.; Ejima, D.; Arakawa, T. A novel protein refolding system using lauroyl-L-glutamate as a solubilizing detergent and arginine as a folding assisting agent. Protein Expr. Purif. 2011, 75, 46-54.

46. Kudou, M.; Ejima, D.; Sato, H.; Yumioka, R.; Arakawa, T. Refolding single-chain antibody (scFv) using lauroyl-L-glutamate as a solubization detergent and arginine as a refolding additive. Protein Expr. Purif. 2011, 7, 68-74.

47. Xia, J.; Nnanna, I.A.; Sakamoto, K. Amino acid surfactants: Chemistry, synthesis, and properties. In Protein-Based Surfactants. Synthesis, Physicochemical Properties, and Applications; Nnanna, I.A., Xia, J., Eds.; Marcel Dekker: New York, NY, USA, 2001; pp. 75-122.

48. Ejima, D.; Watanabe, M.; Sato, Y.; Date, M.; Yamada, N.; Takahara, Y. High yield refolding and purification process for recombinant interleukin-6 expressed in Escherichia coli. Biotechnol. Bioeng. 1999, 62, 301-310.

49. Boone, T.; Chazin, V.; Kenney, W.; Swanson, E.; Altrock, B. Construction, purification and biological activities of recombinant human interleukin-2 analogs. Dev. Biol. Stand. 1988, 69, 157-168.

50. Umetsu, M.; Tsumoto, K.; Hara, M.; Ashish, K.; Goda, S.; Adshiri, T.; Kumagai, I. How additives influence the refolding of immunoglobulin-folded proteins in a stepwise dialysis system. Spectroscopic evidence for highly efficient refolding of a single-chain Fv fragment. J. Biol. Chem. 2003, 278, 8979-8987.

51. Reddy, K.R.C.; Lilie, H.; Rudolph, R.; Lange, C. L-Arginine increases the solubility of unfolded species of hen egg white lysozyme. Protein Sci. 2005, 14, 929-935.

52. Armstrong, N.; de Lencastre, A.; Gouaux, E. A new protein folding screen: Application to the ligand binding domains of a glutamate and kainite receptor and to lysozyme and carbonic anhydrase. Protein Sci. 1999, 8, 1475-1483.

53. Oneda, H.; Inouye, K. Refolding and recovery of recombinant human matrix metalloproteinase (matrilysin) from inclusion bodies expressed by Escherichia coli. J. Biochem. 1999, 126, 905-911.

54. Arora, D.; Khanna, N. Method for increasing the yield of properly folded recombinant human gamma interferon from inclusion bodies. J. Biotechnol. 1996, 52, 127-133.

55. Suenaga, M.; Ohmae, H.; Tsuji, S.; Itoh, T.; Nishimura, O. Renaturation of recombinant human neurotrophin-3 from inclusion bodies using a suppressor agent of aggregation. Biotechnol. Appl. Biochem. 1998, 28, 119-124.

56. Rattenholl, A.; Ruoppolo, M.; Flagiello, A.; Monti, M.; Vinci, F.; Marino, G.; Lilie, H.; Schwarz, E.; Rudolph, R. Pro-sequence assisted folding and disulfide bond formation of human nerve growth factor. J. Mol. Biol. 2001, 305, 523-533. 
57. Asano, R.; Kudo, T.; Makabe, K.; Tsumoto, K.; Kumagai, I. Antitumor activity of interleukin-21 prepared by novel refolding procedure from inclusion bodies expressed in Escherichia coli. FEBS Lett. 2002, 528, 70-76.

58. Bajorunaite, E.; Sereikaite, J.; Bumelis, V. L-arginine suppresses aggregation of recombinant growth hormones in refolding process from E. coli inclusion bodies. Protein J. 2007, 26, $547-555$.

59. Takahashi, S.; Ogasawara, H.; Watanabe, T.; Kumagai, M.; Inoue, H.; Hori, K. Refolding and activation of human prorenin expressed in Escherichia coli: Application of recombinant human renin for inhibitor screening. Biosci. Biotechnol. Biochem. 2006, 70, 2913-2918.

60. Lechtken, A.; Zundorf, I.; Dingermann, T.; Firla, B.; Steinhiber, D. Overexpression, refolding, and purification of polyhistidine-tagged human retinoic acid related orphan receptor RORalpha4. Protein Expr. Purif. 2006, 49, 114-120.

61. Hsih, M.H.; Kuo, J.C.; Tsai, H.J. Optimization of the solubilization and renaturation of fish growth hormone produced by Escherichia coli. Appl. Microbiol. Biotechnol. 1997, 48, 66-72.

62. Wang, X.T.; Engel, P.C. An optimized system for refolding of human glucose 6-phosphate dehydrogenase. BMC Biotechnol. 2009, 9, 19-29.

63. Rudolph, R.; Opitz, U.; Hesse, F.; Riebland, R.; Fischer, S. Reactivation of microbially produced human tissue-type plasminogen activator. In Biotechnology International; North, K., Ed.; Century Press Ltd.: London, UK, 1992; pp. 321-325.

64. Rinas, U.; Risse, B.; Jaenicke, R.; Abel, K.J.; Zettlmeissl, G. Denaturation-renaturation of the fibrin-stabilizing factor XIII a-chain isolated from human placenta: Properties of the native and reconstituted protein. J. Biol. Chem. 1990, 371, 49-56.

65. Ahn, J.H.; Lee, Y.P.; Rhee, J.S. Investigation of refolding condition for Pseudomonas fluorescence lipase by response methodology. J. Biotech. 1997, 54, 151-160.

66. Yancey, P.H.; Clark, M.E.; Hand, S.C.; Bowlus, R.D.; Somero, G.N. Living with water stress: Evolution of osmolyte systems. Science 1982, 217, 1214-1222.

67. Ishibashi, M.; Tsumoto, K.; Ejima, D.; Arakawa, T.; Tokunaga, M. Charatcerization of arginine as a solvent additive: A halophilic enzyme as a model protein. Protein Pept. Lett. 2005, 12, 649-653.

68. Rudolph, R.; Fisher, S. Process for obtaining renatured proteins. US patent 4,933,434, June 12 1990.

69. Tischer, A.; Lilie, H.; Rudolph, R.; Lange, C. L-Arginine hydrochloride increases the solubility of folded and unfolded recombinant plasminogen activator rPA. Protein Sci. 2010, 19, 1783-1795.

70. Lange, C.; Rudolph, R. Suppression of protein aggregation by L-arginine. Curr. Pharm. Biotechnol. 2009, 10, 408-414.

71. Yokoyama, K.; Kunio, O.; Ohtsuka, T.; Nakamura, N.; Seguro, K.; Ejima, D. In vitro refolding process of urea-denatured microbial transgltaminase without pro-peptide sequence. Protein Expr. Purif. 2002, 26, 329-335.

72. Hirai, A.; Tanaka, S.; Kawasaki, H.; Nemoto, N.; Suzuki, M.; Maeda, H. Effects of arginine on aggregates of fatty-acid/potassium soap in the aqueous media. Colloid Polym. Sci. 2006, 284, 520-528. 
73. Nozaki, Y.; Tanford, C. The solubility of amino acids and related compounds in aqueous ethylene glycol solutions. J. Biol. Chem.1965, 240, 3568-3575.

74. Nozaki, Y.; Tanford, C. The solubility of amino acids and related compounds in aqueous urea solutions. J. Biol. Chem. 1963, 238, 4074-4081.

75. Nozaki, Y.; Tanford, C. The solubility of amino acids, diglycine, and triglycine in aqueous guanidine hydrochloride solutions. J. Biol. Chem. 1970, 245, 1648-1652.

76. Nozaki, Y.; Tanford, C. The solubility of amino acids and two glycine peptides in aqueous ethanol and dioxane solutions. Establishment of a hydrophobicity scale. J. Biol. Chem. 1971, 246, 2211-2217.

77. Gekko, K. Calorimetric study on thermal denaturation of lysozyme in polyol-water mixtures. J. Biochem. 1982, 91, 1197-1204.

78. Gekko, K.; Koga, S. Increased thermal stability of collagen in the presence of sugars and polyols. J. Biochem. 1983, 94, 199-205.

79. Liu, Y.; Bolen, D.W. The peptide backbone plays a dominant role in protein stabilization by naturally occurring osmolytes. Biochemistry 1995, 34, 12884-12891.

80. Arakawa, T.; Kita, Y.; Timasheff, S.N. Protein precipitation and denaturation by dimethyl sulfoxide. Biophys. Chem. 2007, 131, 62-70.

81. Arakawa, T.; Timasheff, S.N. Mechanism of protein salting in and salting out by divalent cation salts: Balance between hydration and salt binding. Biochemistry 1984, 23, 5912-5923.

82. Arakawa, T.; Ejima, D.; Tsumoto, K.; Obeyama, N.; Tanaka, Y.; Kita, Y.; Timasheff, S.N. Suppression of protein interactions by arginine: A proposed mechanism of the arginine effects. Biophys. Chem. 2007, 127, 1-8.

83. Tanford, C. Contribution of hydrophobic interactions to the stability of the globular conformation of proteins. J. Am. Chem. Soc. 1962, 84, 4240-4247.

84. Dioguardi, F.S. To give or not to give. J. Nutrigenet. Nutrigenomics 2011, 4, 90-98.

85. Maity, H.; Karkaria, C.; Davagino, J. Mapping of solution components, pH changes, protein stability and the elimination of protein precipitation during freeze-thawing of fibroblast growth factor 20. Int. J. Pharm. 2009, 378, 122-135.

86. Maity, H.; Karkaria, C.; Davagnino, J. Effects of $\mathrm{pH}$ and arginine on the solubility and stability of a therapeutic protein (Fibroblast Growth Factor 20): Relationship between solubility and stability. Curr. Pharm. Biotechnol. 2009, 10, 609-625.

87. Ejima, D.; Yumioka, R.; Arakawa, T.; Tsumoto, K. Arginine as an effective additive in gel permeation chromatography. J. Chromatogr. A 2005, 1094, 49-55.

88. Arakawa, T.; Tsumoto, K.; Nagase, K.; Ejima, D. The effects of arginine on protein binding and elution in hydrophobic interaction and ion-exchange chromatography. Protein Expr. Purif. 2007, 54, 110-116.

89. Tsumoto, K.; Umetsu, M.; Kumagai, I.; Ejima, D.; Arakawa, T. Solubilization of active green fluorescent protein from inclusion particles by guanidine and arginine. Biochem. Biophys. Res. Commun. 2003, 312, 1383-1386.

90. Umetsu, M.; Tsumoto, K.; Nitta, S.; Adschiri, T.; Ejima, D.; Arakawa, T.; Kumagai, I. Nondenaturing solubilization of beta2 microglobulin from inclusion bodies by L-arginine. Biochem. Biophys. Res. Commun. 2005, 328, 189-197. 
91. Yamasaki, H.; Tsujimoto, K.; Koyama, A.H.; Ejima, D.; Arakawa, T. Arginine facilitates inactivation of enveloped viruses. J. Pharm. Sci. 2008, 97, 3063-3073.

92. Katsuyama, Y.; Yamasaki, H.; Tsujimoto, K.; Koyama, A.H.; Ejima, D.; Arakawa, T. Butyroyl-arginine as a potent virus inactivation agent. Int. J. Pharm. 2008, 361, 92-98.

93. Utsunimoya, H.; Ichinose, M.; Tsujimoto, K.; Katsuyama, Y.; Yamasaki, H.; Koyama, A.H.; Ejima, D.; Arakawa, T. Co-operative thermal inactivation of herpes simplex virus and influenza virus by arginine ans $\mathrm{NaCl}$. Int. J. Pharm. 2009, 366, 99-102.

94. Arakawa, T.; Kita, Y.; Koyama, A.H. Synergistic virus inactivation effects of arginine. Biotechnol. J. 2009, 4, 174-178.

95. Tsujimoto, K.; Uozaki, M.; Ikeda, K.; Yamazaki, H.; Utsunomiya, H.; Ichinose, M.; Koyama, A.H.; Arakawa, T. Solvent-induced virus inactivation by acidic arginine solution. Int. J. Mol. Med. 2010, 25, 433-437.

96. Naito, T.; Irie, H.; Tsujimoto, K.; Ikeda, K.; Arakawa, T.; Koyama, A.H. Antiviral effect of arginine against herpes simplex virus type 1. Int. J. Mol. Med. 2009, 23, 495-499.

97. Ohtake, S.; Arakawa, T.; Koyama, A.H. Arginine as a synergistic agent. Molecules 2010, 15, $1408-424$.

98. Nishide, M.; Tsujimoto, K.; Uozaki, M.; Ikeda, K.; Yamasaki, H.; Koyama, A.H.; Arakawa, T. Effects of electrolytes on virus inactivation by acidic solutions. Int. J. Mol. Med. 2011, 27, 803-809.

99. Ikeda, K.; Yamasaki, H.; Minami, S.; Naito, T.; Irie, H.; Arakawa, T.; Koyama, A.H. Virucidal ability of arginine and its possible application as an antiherpetic agent. In From the Hallowed Halls of Herpesvirology; Baines, J., Blaho, J., Eds.; Imperial College Press: London, UK, 2012; Chapter 18, pp. 435-450.

100. Hirano, A.; Kameda, T.; Arakawa, T.; Shiraki, K. Arginine-assisted solubilization system for drug substances: Solubility experiment and simulation. J. Phys. Chem. B 2010, 114, 13455-13462.

101. Arakawa, T.; Kita, Y.; Koyama, A.H. Solubility enhancement of gluten and coumarin by arginine. Int. J. Pharm. 2008, 355, 220-223.

102. Hirano, A.; Arakawa, T.; Shiraki, K. Arginine increases the solubility of coumarin: Comparison with salting-in and salting-out additives. J. Biochem. 2008, 144, 363-369.

103. Arakawa, T.; Uozaki, M.; Koyama, A.H. Modulation of small molecule solubility and protein binding by arginine. Mol. Med. Rep. 2010, 3, 833-836.

104. Gekko, K.; Morikawa, T. Preferential hydration of bovine serum albumin in polyhydric alcohol-water mixtures. J. Biochem. 1981, 90, 39-50.

105. Lee, J.C.; Timasheff, S.N. The stabilization of proteins by sucrose. J. Biol. Chem. 1981, 256, $7193-7201$.

106. Gekko, K.; Timasehff, S.N. Mechanism of protein stabilization by glycerol: Preferential hydration in glycerol-water mixtures. Biochemistry 1981, 20, 4667-4676.

107. Arakawa, T.; Timasheff, S.N. Stabilization of protein structure by sugars. Biochemistry 1982, 21, 6536-6544.

108. Arakawa, T.; Timasheff, S.N. Preferential interactions of proteins with salts in concentrated solutions. Biochemistry 1982, 21, 6545-6552.

109. Kita, Y.; Arakawa, T.; Lin, T.Y.; Timasheff, S.N. Contribution of the surface free energy perturbation to protein-solvent interactions. Biochemistry 1994, 33, 15178-15189. 
110. Lee, J.C.; Timasheff, S.N. Partial specific volumes and interactions with solvent components in guanidine hydrochloride. Biochemistry 1974, 13, 257-265.

111. Prakash, V.; Loucheux, C.; Scheufele, S.; Borbunoff, M.J.; Timasheff, S.N. Interaction of proteins with solvent components in $8 \mathrm{M}$ urea. Arch. Biochem. Biophys. 1981, 210, 455-464.

112. Hong, J.; Capp, M.W.; Anderson, C.F.; Record, M.T. Preferential interactions in aqueous solution of urea and KCl. Biophys. Chem. 2003, 105, 517-532.

113. Timasheff, S.N.; Xie, G. Preferential interactions of urea with lysozyme and their linkage to protein denaturation. Biophys. Chem. 2003, 105, 421-448.

114. Bull, H.B.; Breese, K. Interaction of alcohols with proteins. Biopolymers 1978, 17, 2121-2131.

115. Inoue, H.; Timasheff, S.N. The interaction of beta-lactoglobulin with solvent components in mixed water-organic solvent systems. J. Am. Chem. Soc. 1968, 90, 1890-1898.

116. Timasheff, S.N.; Inoue, H. Preferential binding of solvent components to proteins in mixed water-organic solvent systems. Biochemistry 1968, 7, 2501-2513.

117. Inoue, H.; Timasheff, S.N. Preferential and absolute interactions of solvent components with proteins in mixed solvent systems. Biopolymers 1972, 11, 737-743.

118. Pittz, E.P.; Timasheff, S.N. Interaction of ribonuclease A with aqueous 2-methyl-2,4-pentanediol at pH 5.8. Biochemistry 1978, 17, 615-623.

119. Arakawa, T.; Bhat, R.; Timasheff, S.N. Why preferential hydration does not always stabilize the native structure of globular proteins. Biochemistry 1990, 29, 1924-1931.

120. Arakawa, T.; Timasheff, S.N. Preferential interactions of proteins with solvent components in aqueous amino acid solutions. Arch. Biochem. Biophys. 1983, 224, 169-177.

121. Arakawa, T.; Timasheff, S.N. The mechanism of action of Na glutamate, lysine $\mathrm{HCl}$, and piperazine- $N, N^{\prime}$-bis(2-ethanesulfonic acid) in the stabilization of rubulin and microtuble formation. J. Biol. Chem. 1984, 259, 4979-4986.

122. Arakawa, T.; Timasheff, S.N. The stabilization of proteins by osmolytes. Biophys. J. 1985, 47, 411-414.

123. Arakawa, T.; Timasheff, S.N. Protein stabilization and destabilization by guanidinium salts. Biochemistry 1984, 23, 5923-5929.

124. Arakawa, T.; Timasheff, S.N. Theory of protein solubility. Methods Enzymol. 1985, 114, 49-77.

125. Arakawa, T.; Timasheff, S.N. Abnormal solubility behavior of beta-lactoglobulin: Salting-in by glycine and $\mathrm{NaCl}$. Biochemistry 1987, 26, 5147-5153.

126. Arakawa, T.; Bhat, R.; Timasheff, S.N. Preferential interactions determine protein solubility in three-component solutions: $\mathrm{MgCl}_{2}$ system. Biochemistry 1990, 29, 1914-1923.

127. Schneider, C.P.; Trout, B.L. Investigation of cosolute-protein preferential interaction coefficients: New insight into the mechanism by which arginine inhibits aggregation. J. Phys. Chem. 2009, 113, 2050-2058.

128. Ito, L.; Shiraki, K.; Matsuura, T.; Okumura, M.; Hasegawa, K.; Baba, S.; Yamaguchi, H.; Kumasaka, T. High-resolution X-ray analysis reveals binding of arginine to aromatic residues of lysozyme surface: Implication of suppression of protein aggregation by arginine. Protein Eng. Des. Sel. 2011, 24, 269-274.

129. Shukla, D.; Trout, B. Interaction of arginine with proteins and the mechanism by which it inhibits aggregation. J. Phys. Chem. B 2010, 114, 13426-13438. 
130. Woods, A.S. The mighty arginine, the stable quaternary amines, the powerful aromatics, and the aggressive phosphate: Their role in the noncovalent minuet. J. Proteome Res. 2004, 3, 478-484.

131. Flocco, M.M.; Mowbray, S.L. Planar stacking interactions of arginine and aromatic side-chains in proteins. J. Mol. Biol. 1994, 235, 709-717.

132. Gallivan, J.P.; Dougherty, D.A. Cation-pi interactions in structural biology. Proc. Natl. Acad. Sci. USA 1999, 96, 9459-9464.

133. Crowley, P.B.; Golovin, A. Cation-pi interactions in protein-protein interfaces. Proteins 2005, 59, 231-239.

134. Dougherty, D.A. Cation-pi interactions involving aromatic amino acids. J. Nutr. 2007, 137, 1504S-1508S.

135. Nakakido, M.; Tanaka, Y.; Mitsuhori, M.; Kudou, M.; Ejima, D.; Arakawa, T.; Tsumoto, K. Structure-based analysis reveals hydration changes induced by arginine hydrochloride. Biphys. Chem. 2008, 137, 105-109.

136. Baynes, B.M.; Wang, D.I.; Trout, B.L. Role of arginine in the stabilization of proteins against aggregation. Biochemistry 2005, 44, 4919-4925.

137. Arakawa, T.; Tsumoto, K. The effects of arginine on refolding aggregated proteins: Not facilitate refolding, but suppress aggregation. Biochem. Biophys. Res. Commun. 2003, 304, 148-152.

138. Shiraki, K.; Kudou, M.; Fujiwara, S.; Imanaka, T.; Takagi, M. Biophysical effect of amino acids on the prevention of protein aggregation. J. Biochem. 2002, 132, 591-595.

(C) 2012 by the authors; licensee MDPI, Basel, Switzerland. This article is an open access article distributed under the terms and conditions of the Creative Commons Attribution license (http://creativecommons.org/licenses/by/3.0/). 